\title{
New EU Directive on the Disclosure of Non-Financial Information (CSR)
}

\author{
by \\ Dániel Gergely Szabó and Karsten Engsig Sørensen*
}

In October 2014, the EU adopted new rules on the disclosure of non-financial information, otherwise known as corporate social responsibility (CSR) information. The new requirements bring the CSR disclosure regulation in the EU in line with the current best practices and constitute a huge step forward compared to the existing rules on the disclosure of non-financial information.

This article analyses the likely impact of the amended Accounting Directive, its scope of application, what should be disclosed and how the new provisions of the Directive should be enforced. In doing so, the article compares the new requirements to current best practices and experiences, especially using the experiences with mandatory CSR reporting in Denmark and the experiences with corporate governance reporting in the EU. Based on these experiences, the article also makes predictions of whether the new requirements are likely to increase the quantity of the non-financial information disclosed and the consistency and comparability of the reports. ${ }^{1}$

\section{Table of Contents $\quad$ ECFR 2015, 307-340}

I. Introduction . . . . . . . . . . . . . . . . . . . . 308

II. The background of the new requirement . . . . . . . . . . . . 311

1. CSR reporting in the EU and its Member States: a brief history . . . . 311

2. Why harmonise?. . . . . . . . . . . . . . . . 314

III. Undertakings obliged to disclose . . . . . . . . . . . . . . . . 318

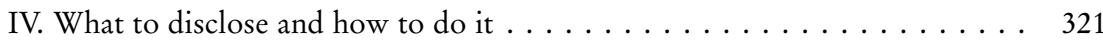

1. What should be disclosed? . . . . . . . . . . . . . . 321

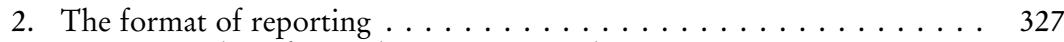

3. Duty to explain if no policies are pursued . . . . . . . . . . 331

V. Exceptions to the duty to disclose a non-financial statement . . . . . . . . 333

1. Reporting under alternative frameworks . . . . . . . . . . . 334

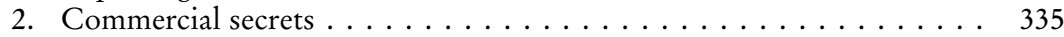

* Postdoc, PhD Dániel Gergely Szabó and Professor, dr.jur. Karsten Engsig Sørensen, Department of Law, Aarhus University.

1 The topic of the new EU non-financial reporting requirements is also addressed in the context of the preceding reporting requirement and the proposal for the new requirements in subchapter 3.4 of the forthcoming book of Dániel Gergely Szabó, see Dániel Gergely Szabó, Mandatory Corporate Social Responsibility Reporting in the EU, Dovenschmidt Monographs Series, Eleven International Publishing, forthcoming in 2015. 


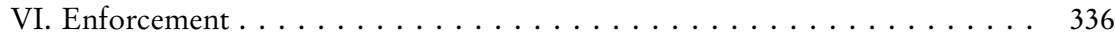

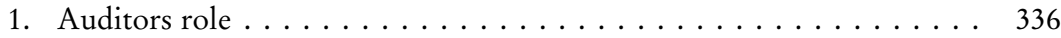

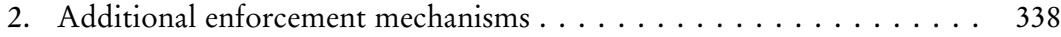

VII. Conclusion . . . . . . . . . . . . . . . . . . . . . . . . . 339

\section{Introduction}

As late as 2011, the Commission launched the idea that the EU should help to improve the undertakings' disclosure of social and environmental information. ${ }^{2}$ In 2013, the Commission proposed a new directive ${ }^{3}$ and this directive was passed in 2014 - less than three years after launching the idea. The new directive, $\mathrm{Di}$ rective 2014/95/EU, (hereafter the "amending directive" or "directive") is amending the consolidated Accounting Directive, Directive 2013/34/EU, (hereafter the "Accounting Directive" or "Directive") with the introduction of rules on the disclosure of non-financial and diversity information. This relatively fast sequence of events indicates that the topic is both important and topical.

The main element of the amending directive is that it introduces a duty for larger undertakings to report on their business model, policy, principal risks and key performance indicators (KPIs) in relation to several matters in the ambit of corporate social responsibility (CSR), including environmental, social and employee matters, respect for human rights, and anti-corruption and bribery matters. This information is to be reported in a 'non-financial statement' ${ }^{5}$ which should be included in the management report of the undertaking. The new requirements will take effect for the reports that undertakings have to submit covering the 2017 financial year.

Before the adoption of this directive, there was very little focus on the disclosure of non-financial information, thus this directive constitutes a novel development in EU law. Most Member States do not have rules dictating a

2 See Communication from the Commission to the European Parliament, the Council, the European Economic and Social Committee and the Committee of the Regions, A renewed EU strategy 2011-14 for Corporate Social Responsibility, COM(2011) 681 final, 25. 10. 2011, p. 11-12.

3 See Proposal for a Directive of the European Parliament and of the Council amending Council Directives 78/660/EEC and 83/349/EEC as regards disclosure of nonfinancial and diversity information by certain large companies and groups, $\operatorname{COM}(2013) 207$ final, 16. 4. 2013.

4 See Directive 2014/95/EU of the European Parliament and of the Council of 22 October 2014 amending Directive 2013/34/EU as regards disclosure of non-financial and diversity information by certain large undertakings and groups, OJ L 330, 15.11.2014.

5 It is interesting to note that the amending directive does not refer to CSR or CSR policies at all. 
comprehensive disclosure regime on CSR such as is required in the amending directive, and thus the directive will also introduce rules that are novel in most Member States. ${ }^{6}$ Therefore it is important to analyse the directive to better understand what the undertaking should disclose and how, as well as analysing how the rules should be implemented.

Denmark introduced very similar disclosure rules in 2008, taking effect in 2009. Denmark has thus gained experience with such a disclosure regime. ${ }^{7}$ Therefore, the Danish experiences will be called upon where relevant for understanding how the new rules introduced in the directive will likely work. ${ }^{8}$

The amending directive also introduces disclosure rules on diversity information. ${ }^{9}$ This refers to the diversity policy applied in relation to an undertaking's administrative, management and supervisory bodies with regard to, for instance, age, gender, or educational and professional background. This disclosure should be made as part of the corporate governance statement. ${ }^{10}$ The directive

6 See Commission Staff Working Document, Impact Assessment Accompanying the document Proposal for a Directive of the European Parliament and of the Council amending Council Directives 78/660/EEC and 83/349/EEC as regards disclosure of non-financial and diversity information by certain large companies and groups, $\operatorname{SWD}(2013) 128$ final, 16.4. 2013, pp.49-54; Katelijne van Wensen, Wijnand Broer, Johanna Klein, and Jutta Knopf, The State of Play in Sustainability Reporting in the European Union, available at http://ec.europa.eu/social/BlobServlet?docId=6727\&langId=en, 2011; Carrots and Sticks: Sustainability reporting policies worldwide - today's best practice, tomorrow's trends, 2013 edition, available at https://www.globalreporting.org/resourcelibrary/car rots-and-sticks.pdf, 2013; KPMG, Survey of Corporate responsibility reporting 2013, available at http://www.kpmg.com/Global/en/IssuesAndInsights/ArticlesPublications/corporate-responsibility/Documents/kpmg-survey-of-corporate-responsibilityreporting-2013.pdf, 2013.

7 See Danish law no. 1403 from 27 December 2008. For a short account of the Danish rules see the webpage of the responsible Danish agency at http://csrgov.dk/legislation. Additionally see Karin Buhmann, The Danish CSR reporting requirement as reflexive law: Employing CSR as a modality to promote public policy, European Business Law Review, vol. 24, issue 2, 2013, pp. 187-216.

8 Discussing further non-financial reporting regimes as a basis for insight or comparison, and comparing the new EU non-financial reporting requirements and such financial reporting and accounting standards as the GAAP and IAS/IFRS is well beyond the confines and subject of this article. Other non-financial reporting requirements adopted by various EU Member States will only be mentioned as part of the historical background to the adoption of the new EU non-financial reporting requirements, see section 2.1.

9 See Article 1(2) of Directive 2014/95/EU of the European Parliament and of the Council of 22 October 2014 amending Directive 2013/34/EU as regards disclosure of nonfinancial and diversity information by certain large undertakings and groups, OJ L 330, 15.11.2014.

10 See Article 20 of Directive 2013/34/EU of the European Parliament and of the Council of 26 June 2013 on the annual financial statements, consolidated financial statements and related reports of certain types of undertakings, amending Directive 2006/43/EC of the 
does not make any logical connection between the disclosure of non-financial information and diversity information. Even though both deal with the disclosure of certain non-financial information, their policy aims differ as well as the method of disclosure. The ultimate aim of the disclosure of the aforementioned non-financial information appears to be to manage change towards a sustainable global economy by combining long-term profitability with social justice and environmental protection. ${ }^{11}$ The aim for introducing a duty to disclose the details of the diversity policy is to avoid what is known as 'group-think' - e.g. to facilitate a better understanding of the business organisation and the affairs of the undertaking by having more diverse competences and views represented in the management. ${ }^{12}$ As also mentioned above, the non-financial statement is disclosed as a separate statement whereas the diversity policy will be published as part of the corporate governance statement. Because there is no necessary link between the two disclosure regimes the duty to disclosure the undertakings' diversity policy will not be dealt with in the following. ${ }^{13}$

Section 2 explains the background of the amending directive. Section 3 analyses which undertakings will be required to make disclosures according to the new requirement, and section 4 analyses what should be disclosed and how. Section 5 analyses the exceptions from the duty to disclose, and section 6 analyses the different ways that ensure compliance with the duty to disclose. Section 7 concludes.

European Parliament and of the Council and repealing Council Directives 78/660/EEC and 83/349/EEC, OJ L 182, 29.6.2013.

11 See recital 3 of Directive 2014/95/EU.

12 See recital 18 of Directive 2014/95/EU. The link between diversity and good corporate governance was made first by the Commission Green Paper, The EU corporate governance framework, $\operatorname{COM}(2011) 164$ final, 5.4.2011, pp.6-7, where the Commission argued that gender diversity may improve the quality of the work of boards, although it admits that the evidence is nuanced.

The argument could be made that promoting diversity - especially gender diversity could also promote the more sustainable development of the undertaking, and thereby achieve the same goal pursued by the requirement to disclose non-financial information. There is some evidence that indicates that women are more inclined to promote CSR values and therefore more women on boards could enhance CSR; see Nabil A. Ibrahim \& John P Angelidis, Effects of Boards Members' Gender on Corporate Social Responsiveness Orientation, Journal of Applied Business Research, Vol. 10, 1994, pp. 35-40. However, as mentioned, the Commission does not try to make such a link between nonfinancial reporting and diversity reporting.

13 The amending directive also provides that the Commission should contemplate whether to introduce rules requiring the undertakings or groups to disclose country-by-country reports for each country in which they operate containing information on, as a minimum, taxes paid, profits and public subsidies received, see recital 20 and Article 1(6) of Directive 2014/95/EU. These vague ideas for additional disclosure obligation will not be addressed further in this article. 


\section{The background of the new requirement}

\section{CSR reporting in the EU and its Member States: a brief history}

The concept of CSR originated some sixty years ago ${ }^{14}$ and has been a concept that includes a wide variety of issues and themes ever since..$^{15}$ Although, the concept of CSR has been changing significantly over time in order to follow the changes in societal interests and expectations associated with undertakings ${ }^{16}$ one aspect of the understanding of the notion has remained constant for a long time: most sources defined CSR as a purely voluntary effort on the part of undertakings. Firstly, most academics defined CSR as a voluntary effort, i.e. an extra-legal effort or an effort beyond that of legal requirements, by undertakings. ${ }^{17}$ Secondly, the European Commission also defined CSR in its first and most comprehensive policy paper on CSR as an effort or activity by the companies undertaken 'on a voluntary basis'. ${ }^{18}$ Consequently, CSR has, for some time, only been addressed through disclosure regulation in the EU. ${ }^{19}$ The same is generally also true to the Member States of the EU. ${ }^{20}$

Originally, however, neither the provisions of the Fourth Company Law Directive nor those of the Seventh Company Law Directive relating to the management report expressly required the disclosure of any CSR information. ${ }^{21}$ This was fully in conformity with the EU policy that CSR should be

14 Howard R. Bowen, Social responsibilities of the businessman, Harper, 1953.

15 See, e.g., Tineke Lambooy, Corporate Social Responsibility: Legal and Semi Legal Frameworks, Kluwer Law International, 2010, p. 10.

16 See Archie B. Carroll, Chapter 2 - A History of Corporate Social Responsibility: Concepts and Practices, in: Andrew Crane, Abagail McWilliams, Dirk Matten, Jeremy Moon, and Donald S. Siegel, (eds), The Oxford Handbook of Corporate Social Responsibility, Oxford University Press, 2008, pp. 20-24.

17 Beate Sjåfjell, If not now, then when?: European Company Law in a Sustainability Development Perspective, European Company Law, Vol. 7, Issue 5, 2010, pp. 184-197.

18 Commission Green Paper, Promoting a European framework for Corporate Social Responsibility, $\operatorname{COM}(2001) 366$ final, 18.7.2001, p. 6.

19 See Commission Recommendation 2001/453/EC of 30 May 2001 on the recognition, measurement and disclosure of environmental issues in the annual accounts and annual reports of companies, notified under document number C(2001) 1495, OJ L 156/33, 13.6. 2001 and subsequent Directive 2003/51/EC of the European Parliament and of the Council of 18 June 2003 amending Directives 78/660/EEC, 83/349/EEC, 86/635/EEC and $91 / 674 / \mathrm{EEC}$ on the annual and consolidated accounts of certain types of companies, banks and other financial institutions and insurance undertakings, OJ L 178, 17. 7.2003.

20 See a brief discussion of some Member States' regulatory approaches other than mandatory disclosure in footnote 46.

21 See Article 46 of the Fourth Council Directive 78/660/EEC of 25 July 1978 based on Article 54(3)(g) of the Treaty on the annual accounts of certain types of companies, OJ L 222/11, 14.8.1978 and Article 39 of the Seventh Council Directive 83/349/EEC of 
undertaken voluntarily and consequently should not be subject to binding regulation. ${ }^{22}$ The first crack in this policy emerged when the first attempt of the EU to regulate the CSR activities of European undertakings came about in 2003 with the adoption of the Accounts Modernisation Directive. ${ }^{23}$ This Directive amended the Accounting Directives so as to oblige undertakings to report in their management reports on the relevant non-financial KPIs, such as the ones related to environmental and employee matters.

However, partly due to the lack of maturity in the area of CSR reporting, partly due to the enduring notion that CSR should not be subject to regulation, the requirement remained conditional and rather vague. Since the requirement was not supported by binding reporting standards or even by non-binding guidelines, this reporting requirement did not have the intended impact, as undertakings seldom reported on non-financial issues. Even the EU had to acknowledge that the rules on the disclosure of non-financial information were in need of improvement in the EU. ${ }^{24}$

Among the Member States there was no consensus about the importance of non-financial reporting either. While some Member States were satisfied with merely transposing the provisions of the Accounts Modernisation Directive in various ways and with diverging scopes, ${ }^{25}$ other Member States went further and required the disclosure of non-financial information beyond that of the provisions of the Accounts Modernisation Directive. But even these latter requirements varied greatly in regards to form and scope. Some Member States opted to limit the non-financial reporting requirements to certain aspects of CSR; others opted to significantly limit the scope of undertakings subjected to their requirements. Several Member States mandated some measure of environmental accounting and reporting, mostly affecting undertaking posing potential environmental hazard, already prior to the adoption of the Accounts Modernisation Directive. ${ }^{26}$ However, these requirements were more closely related to financial reporting, than non-financial reporting in the sense of this article. The UK focused on a limited aspect of environmental concerns instead

13 June 1983 based on Article 54(3)(g) of the Treaty on consolidated accounts, OJ L 193/ 1, 18.7.1983.

22 Commission Green Paper, Promoting a European framework for Corporate Social Responsibility, 18.7.2001, p 6.

23 Directive 2003/51/EC.

24 Commission Staff Working Document, Impact Assessment, 16. 4. 2013, pp. 10-12.

25 Tineke Lambooy and Nicole van Vliet, Transparency on Corporate Social Responsibility in Annual Reports, European Company Law, Vol. 5, Issue 3, 2008, pp. 129-131.

26 See, e.g., Denmark, the Netherland, Spain, Norway and Sweden. See Carlos Larrinaga, Francisco Carrasco, Carmen Correa, Fernando Llena and José M. Moneva, Accountability and accounting regulation: the case of the Spanish environmental disclosure standard, European Accounting Review, Vol. 11, Issue 4, 2002, pp. 724-725 . 
and mandated greenhouse gas emission reporting for quoted undertakings, ${ }^{27}$ which represents environmental reporting on its own right, separate from financial reporting. Some Member States, such as Finland and Sweden, chose a different path and introduced a more general non-financial reporting obligation but for state-owned undertakings only. ${ }^{28}$

The most comprehensive and inclusive non-financial reporting requirements have been adopted by France and Denmark. While Denmark introduced its mandatory CSR reporting regime in 2008, ${ }^{29}$ the regime of France has been in the force since $2001 .{ }^{30}$ Although both regimes mandated non-financial disclosure for large companies, they did it slightly differently. The French NRE law introduced a list of 68 items of non-financial information that had to be reported on. The reporting requirements have been extended with the 2010 revision of the legislation by the Grenelle II Act to all limited companies. ${ }^{31}$ Although this new legislation aimed at increasing flexibility by accommodating different modes of compliance with the requirements, it remained a highly detailed regime that prescribes the disclosure of relatively specific non-financial topics. ${ }^{32}$ The Danish regime tackled the CSR reporting challenge by creating flexible reporting requirements in which only the broader reporting topics were prescribed; choosing the mode of compliance was largely up to the individual undertaking.

Meanwhile the policy approach that regarded CSR as purely voluntary eroded even further at EU level. In its latest CSR strategy the EU Commission no longer defined CSR as a purely voluntary effort as the Commission suggested that public authorities should facilitate the undertakings' efforts of becoming more socially responsible by adopting complementary regulation. ${ }^{33}$ The strat-

27 See Part 7 of The Companies Act 2006 (Strategic Report and Direct ors' Report) Regulations 2013.

28 See KPMG, Carrots and Sticks: Sustainability reporting policies worldwide-today's best practice, tomorrow's trends, 2013 edition, available at https://www.globalreporting. org/resourcelibrary/carrots-and-sticks.pdf, 2013, p. 61, 75.

29 See the reference in footnote 7.

30 Olivier Delbard, CSR legislation in France and the European regulatory paradox: an analysis of EU CSR policy and sustainability reporting practice, Corporate Governance: The international journal of business in society, Vol. 8, Issue 4, 2008, pp. 399-400.

31 Institute RSE Management, The Grenelle II Act in France: a milestone towards integrated reporting, available at https://www.capitalinstitute.org/sites/capitalinstitute.org/ files/docs/Institut \%20RSE\%20The\%20grenelle\%20II\%20Act $\% 20 \mathrm{in} \% 20$ France $\% 20$ June\%202012.pdf, 2012, p. 5.

32 Institute RSE Management, The Grenelle II Act in France: a milestone towards integrated reporting, available at https://www.capitalinstitute.org/sites/capitalinstitute.org/ files/docs/Institut \%20RSE\%20The\%20grenelle\%20II\%20Act $\% 20$ in $\% 20$ France $\% 20$ June\%202012.pdf, 2012, pp. 7, 10-13.

33 Communication from the Commission, A renewed EU strategy, 25.10.2011, pp.6-7. 
egy specifically mentioned transparency regulation as an example of complementary regulation that can be adopted to facilitate CSR. ${ }^{34}$

As a consequence of this development, and after several public consultations and expert group opinions, the EU adopted new, more elaborate reporting rules in October 2014. ${ }^{35}$ As will be seen from section 4, the new rules require the disclosure of more non-financial information and require disclosure in a more structured way than ever before at EU level. It seems that the Danish regime have been the model for at least part of the new rules, and consequently the Danish experiences are relevant when evaluating these. ${ }^{36}$

\section{Why harmonise?}

The Commission identified the goal of further harmonisation in the area of non-financial reporting at EU level in its 2011 Communication on the Single Market Act. ${ }^{37}$

When taking a closer look at the background of why the EU legislator thinks that there is a need for harmonisation, it appears to be based mainly on the EU Commission's assumption that users, especially investors, are actually interested in social and environmental information ${ }^{38}$ and that the EU asset management industry should also be used 'to pursue objectives of general interest or [interests] relating to social, ethical or environmental development. ${ }^{39}$ The latter statement of the Commission being normative, rather than descriptive, in nature gives the impression that the actual use of the social and environmental information by the aforementioned users is rather wishful thinking than well-founded fact. ${ }^{40}$ It appears as if the Commission expects a rise in

34 Ibid., p. 7.

35 Directive 2014/95/EU.

36 For the same reason there are several references to the Danish experiences in the impact assessment made of the new Directive, see the reference in or at footnote 116, 124, 183, 185 and 208 of the Commission Staff Working Document, Impact Assessment, 16. 4.2013.

37 Communication from the Commission to the European Parliament, the Council, the Economic and Social Committee and the Committee of the Regions, Single Market Act - Twelve levers to boost growth and strengthen confidence "Working together to create new growth", COM(2011) 206 final, 13.4.2011.

38 Commission Staff Working Document, Impact Assessment, 16. 4.2013, p. 23.

39 Communication from the Commission, Single Market Act, 13.4.2011, p. 15.

40 If there was a demand, one would expect the information to be produced unless there is a 'market failure' that prevents this from happening. The Commission does not explicitly address this question, but there are arguments for why it is necessary to introduce mandatory disclosure rules on CSR. First, the information that is produced may not be reliable unless supported by mandatory rules, given especially that undertakings tend 
the use of the information by investors and other users if more and better information is made available. Thus the incentive to harmonise does not only appear to come from the high demand of non-financial information, but from the normative stance of the EU legislator to create, or at least boost, the demand for such information at the same time by increasing transparency of the information.

It is worth noting that the EU legislator does not rely on the 'business case' as an argument for introducing harmonisation. The 'business case' refers to the assertion that the pursuit of CSR activities and the disclosure of CSR information would be profitable to undertakings in the long run. In comparison, the Danish legislator relied on the business case when it introduced the disclosure requirement in $2009 .{ }^{41}$ However, given that the business case cannot be proven empirically, it may be a wise decision not to rely too much on this as an argument for introducing harmonised rules in the area. ${ }^{42}$ At the same time,

not to report on less positive aspects of their CSR policy and may be induced to produce misleading information. Next, there is a great need for ensuring that the disclosed information can be compared and such comparability may likewise require legislation. On the theory when disclosure may or should be mandated see for instance Frank H. Easterbrook and Daniel R. Fischel, The Economic Structure of Corporate Law, Harvard University Press, 1996, pp. 276-314, and Anthony Ogus, Regulation; Legal Form and Economic Theory, Hart Publishing, 2004. More specifically on the need to mandate disclosure on non-financial information see Rory Sullivan, Valuing Corporate Responsibility: How Do Investors Really Use Corporate Responsibility Information?, Greenleaf Publishing, 2011, pp. 64-65, and Shane Heitzman, Charles Wasley and Jerold Zimmerman, The joint effects of materiality thresholds and voluntary disclosure incentives on firms' disclosure decisions, Journal of Accounting and Economics, Vol. 49, Issues 1-2, 2010.

41 It is clear from the explanations for proposing the act in the Proposal for an Act amending the Danish Financial Statements Act (Proposal L 5 from 2008), pp. 4-5. However, even here they do acknowledge that it may not be all undertakings that profit from disclosing CSR-related information.

42 The Commission in the Commission staff working document, European competitiveness report 2008, SEC (2008) 2853 final, 28.111.2008, pp. 106-121 points out that having a responsible profile may enhance the competitiveness of undertakings in various ways. The business case is often mentioned in the literature as an argument for why undertakings should adopt a CSR policy, see for instance Oliver De Schutter, Corporate Social Responsibility European Style, European Law Journal, Vol. 14, Issue 2, 2008, pp. 203 236, and Jan Wouters \& Leen Chanet, Corporate Human Rights Responsibility: A European Perspective, Northwestern University of International Human Rights, vol. 6, 2008, pp. 262-303. But empirical research does not appear able to establish the business case, see for instance Urs von Arx \& Andreas Zeigler, The Effect of CSR on Stock Performance: New Evidence for the USA and Europe, Working Paper, CER-ETH 08/85, available at http://papers.ssrn.com/sol3/papers.cfm?abstract_id=1102528, 2008; Oliver Salzmann, Aileen Ionescu-Somers \& Ulrich Steger, The Business Case for Corporate Sustainability: Literature Review and Research Options, European Management Jour- 
since the Commission already argues that the investors and other users indeed desire more non-financial information, it appears presupposed that the business case is valid to some extent at EU level as well.

Even though the aim does not appear to be to enhance the competitiveness or profitability of the undertakings, the ultimate aim of the amending directive is to affect how business is conducted. According to the preamble the enhanced information disclosure should facilitate a 'change towards a sustainable global economy by combining long-term profitability with social justice and environmental protection. ${ }^{33}$ It is only explained indirectly how the harmonisation of disclosure requirements should achieve this: it is stated that disclosure helps measuring and monitoring the undertakings' impact on society. ${ }^{44}$ Thus it is assumed that the investors and other stakeholders may press the management toward conducting business in a more sustainable way.

There are a lot of sub-assumptions here: not only is it assumed that investors and other stakeholders are interested in CSR information, but also that they are in favour of a more sustainable business profile. Additionally it is presupposed that they have the power to impose this preference on the management. All these assumptions may be called into question, so at the end of the day it is a question of whether one believes that there is an interplay between the undertakings' sustainability profile and the availability of reliable non-financial information.

By allowing investors to press the business into having a more sustainable profile, the EU legislator avoids to regulate in detail how best to achieve such a change. Thus the disclosure regulation is a relatively cheap and non-intrusive way of trying to promote change towards sustainability. ${ }^{45}$ It also has the

nal, vol. 23, issue 1, 2005, pp. 27-36; Marc Orlitzky, Chapter 5, Corporate Social Performance and Financial Performance: A Research Synthesis, in: Andrew Crane, Abagail McWilliams, Dirk Matten, Jeremy Moon and Donald S. Siegel (eds), The Oxford Handbook of Corporate Social Responsibility, Oxford University Press, 2008), pp. 113-114; and Kevin Campbell \& Douglas Vick, Disclosure law and the market for corporate social responsibility, in Doreen McBarnet, A. Voiculescu \& T. Campbell (eds), The New Corporate Accountability, Cambridge University Press, 2009, pp. 241-278.

43 See recital 3 of Directive 2014/95/EU.

44 See recital 3 of Directive 2014/95/EU.

45 It is also difficult to see how a more sustainable business practices should be achieved by the adoption of a different approach than mandatory disclosure considering the diversity of undertakings and their widely varying activities. An alternative would be to change the duty of directors or the purpose of companies (and other undertakings), but these appear to be more complicated solutions (although these solutions have been advocated by some, see for instance Beate Sjåfjell and Jukka Mähönen, Upgrading the Nordic Corporate Governance Model for Sustainable Companies (European Company Law, Vol. 11, Issue 2, 2014). The adoption of the 'enlightened shareholder value' prin- 
benefit of being a flexible legislative instrument, ${ }^{46}$ as it allows the undertakings to adopt the CSR policy they favour and even to abstain from adopting a policy if that suits them best. ${ }^{47}$ Disclosure regulation is also a logical first step as it may provide the legislators with the necessary information on the basis of which it can adopt different types of substantive, more costly and more intrusive legislation.

But even if there appears to be a case for introducing rules on mandatory nonfinancial disclosure it could be argued that in accordance with the principle of subsidiarity the introduction of such rules should be left to the Member States. The main argument for harmonisation appears to be that most of those undertakings targeted by the amending directive operate in more than one Member State. ${ }^{48}$ If undertakings - often as groups of companies - operate in several Member States, it would impose additional costs if they had to comply with different disclosure regimes, ${ }^{49}$ see a short discussion of the various approaches to non-financial reporting adopted by various EU Member States in section 2.1. Another argument is that the shares in these undertakings (especially listed companies) are frequently traded cross-border, which causes a need for comparability of the CSR-related information. If the premise that the investors are interested in monitoring CSR-related activities is accepted, the com-

ciple in UK company law is an example of such regulation, but is considered by most scholars too vague and broad to have much, if any, effect, see for example Andrew Keay, Tackling the issue of the corporate objective: an analysis of the United Kingdom's 'enlightened shareholder value approach', Sydney Law Review, Vol. 29, Issue 4, 2007, pp.610-612; Andrew Keay and Hao Zhang, An analysis of enlightened shareholder value in light of ex post opportunism and incomplete law, European company and financial law review, Vol. 8, Issue 4, 2011, pp. 474-475; and Richard Williams, Enlightened shareholder value in UK company law, University of New South Wales Law Journal, Vol. 35, Issue 1, 2012, pp. 376-377.

46 This flexibility is also pointed out in recital 3 of Directive 2014/95/EU the preamble.

47 The importance of adopting flexible solutions was pointed out by many of the undertakings that participated in the Public Consultation on Disclosure of Non-financial Information by Companies, see DG for the Internal Market and Services, Summary report of the responses received to the Public Consultation on Disclosure of Non-financial Information by Companies, available at http://ec.europa.eu/internal_market/consul tations/docs/2010/non-financial_reporting/summary_report_en.pdf, 2011, p.8. The NGOs on the other hand stressed the importance of clearer compulsory disclosure requirements. This need to balance flexibility and clear rules can be recognised both in the choice of legislative instrument (see the main text below) and in several provisions of the amending directive.

48 See recital 4 of Directive 2014/95/EU.

49 This problem was also pointed out by the Communication from the Commission, $A$ renewed EU strategy, 25.10.2011, p. 11. 
parison of CSR reports between listed companies in different Member States should be made easier. ${ }^{50}$

The Commission contemplated to propose minimum-harmonisation, full harmonisation through the introduction of detailed rules or full harmonisation through the introduction of mandatory EU standards. ${ }^{51}$ Despite of the better disclosure results projected for the full harmonisation approaches, the Commission opted for the significantly cheaper minimum harmonisation approach..$^{52}$ The Commission argues that the minimum harmonisation approach is adopted to avoid the one-size-fits-all approach, thus maintaining flexibility for all undertakings, and avoiding non-financial reporting becoming a mere box-ticking exercise..$^{53}$ Additionally, minimum harmonisation has the advantage of allowing Member States to introduce additional disclosure requirements. Although minimum harmonisation has these advantages, it also has the disadvantage that if Member States adopt additional disclosure requirements, it may still be difficult for undertakings that operate in several Member States to cope with the different requirements. Therefore maximum harmonisation would probably serve the groups of companies operating cross-borders better.

\section{Undertakings obliged to disclose}

According to Article 19a(1) Public Interest Entities averaging more than 500 employees during the financial year must disclose a non-financial statement. 'Public Interest Entities' are defined in the Accounting Directive as either listed companies traded on a regulated market within the EU, credit institutions and insurance undertaking or entities designated as public interest by the Member States. ${ }^{54}$

Additionally, parent undertakings which are Public Interest Entities and which are parents of a group with more than 500 employees have to make a consolidated non-financial statement, see Article 29a(1). A 'parent undertaking' means an undertaking that controls one or more subsidiary undertakings. ${ }^{55}$ Only the parent undertaking needs to be a Public Interest Entity; the subsidiaries may be any kind of undertaking and may be situated anywhere in

50 Recital 6 of the amending directive stresses the need to enhance consistency and comparability in the information disclosed.

51 Commission Staff Working Document, Impact Assessment, 16. 4. 2013, pp. 24-31.

52 Ibid., pp. 30-31.

53 Ibid., pp. 28-29.

54 See Article 2(1) of Directive 2013/34/EU.

55 See Article 2(9) of Directive 2013/34/EU. A more detailed definition of control is found in Article 22 of the Directive. 
the world. When calculating the 500 employees, all employees of the parent and the subsidiaries have to be taken into account.

The consolidated non-financial statement has to meet the same requirement as the statement according to Article $19 \mathrm{a}$, but for the fact that the consolidated statement has to focus on the activities of the whole group. The discussion of the reporting requirement below will focus on statements according to Article 19 a, but will apply mutatis mutandis to the consolidated statements.

If a parent undertaking needs to make a consolidated account according to Article $29 \mathrm{a}$, there is no requirement for the parent undertaking to make a statement according to Article 19 a covering only its own activities. ${ }^{56}$ Similarly, if a subsidiary in a group is itself a Public Interest Entity that would normally have to prepare a statement or a consolidated statement, it does not need to do so if it is covered by the consolidated statement prepared by its parent. ${ }^{57}$ This solution makes sense since the purpose of the consolidated statement is to cover the activities of the whole group. If the parent undertaking is situated outside the EU, the parent will not be obliged to produce a consolidated management statement and therefore the exception will not apply. ${ }^{58}$

According to the Commission, the new requirement will apply to approximately 6,000 large undertakings and groups across the EU.59 This is a significantly lower number than the 18,000 undertakings which would have been covered according to the proposal made in $2013 .{ }^{60}$ The main difference between the proposal and the amending directive finally adopted stem from the fact that the proposal covered all large undertakings not just Public Interest Entities. The reason for limiting the scope to undertakings with more than 500 employees appears to be the need to avoid imposing excessive administrative burdens and costs on smaller undertakings. ${ }^{61}$ During the public con-

56 See Article 29a(2) of Directive 2013/34/EU.

57 Thus according to Article 19a(3) and Article 29a(3) of Directive 2013/34/EU, such subsidiaries are exempted from making both normal statements and consolidated statements.

58 The wording indicates that the parent undertaking has to draw up a consolidated management account according to Article 29 of Directive 2013/34/EU and thus does not appear to allow for the situation to exempt a subsidiary where a parent undertaking situated outside the EU voluntarily forms its management report in a way comparable to Article 29.

59 See the Statement by the Commission on 29. 9.2014, Disclosure of non-financial Information: Europe's largest companies to be more transparent on social and environmental issues (STATEMENT/14/291).

60 See Proposal for a Directive, COM(2013) 207 final, 16. 4.2013, p. 7.

61 See also recitals 13-14 of Directive 2014/95/EU. The impact assessment (p. 28) estimates that the expected cost per annum per undertaking is 600-4,300 EUR if the minimum harmonisation approach is adopted (what they finally did) and 33,000-604,000 EUR if a 
sultation conducted in 2011, many undertakings indicted that only large undertakings should be covered by the new requirement. ${ }^{62}$ Therefore it is not surprising that smaller undertakings are not covered. However, it should be noted that the scope of the directive is rather limited, as 6,000 large undertakings across the EU is a relatively low number. ${ }^{63}$ In comparison, approximately 1,100 undertakings are covered by the Danish reporting requirement alone. ${ }^{64}$

It is possible that more undertakings will be included in a future revision of the Accounting Directive, based on the experiences with the application of the new disclosure requirement. In the meantime the Member States are free to require more undertakings to prepare statements according to the amending directive. ${ }^{65}$ The directive is thus not aiming at a maximum harmonisation as it does not prevent stricter national requirements.

full harmonisation approach is adopted. A survey among the Danish undertakings showed that the costs were between 6,500 and 32,700 DKK (approximately between 850 and 4,300 EUR) which was 7-8 times higher than assumed by the Danish legislator when it introduced the legislation, see the report, Samfundsansvar og Rapportering $i$ Danmark - Effekten af rapporteringskrav i arsregnskabsloven, available at http://sam fundsansvar.dk/file/319079/samfundsansvar_og_rapportering_i_danmark_september_ 2010.pdf, 2010, p. 5. These figures are only an estimate of the cost of reporting incurred by the companies, not the cost associated with implementing CSR policies.

62 See the answer to question 9 in DG for the Internal Market and Services, Summary report of the responses received to the Public Consultation on Disclosure of Non-financial Information by Companies, available at http://ec.europa.eu/internal_market/consulta tions/docs/2010/non-financial_reporting/summary_report_en.pdf, 2011.

63 This does not mean that the Directive will be without effect as the Commission estimates that only 2,500 EU undertakings disclose non-financial information annually, see Proposal for a Directive, $\operatorname{COM}(2013) 207$ final, 16. 4. 2013, p. 4. On the other hand, this number appears very low, considering that CSR or sustainability reporting is mandatory in Denmark and several other countries in the EU, and in Denmark alone approximately 1,100 undertakings are obliged to report annually. In addition, approximately half of the 8,000 signatories of the Global Compact are EU businesses and these have to produce a Communication on Progress report each year. Although, probably not all these undertakings are among the largest undertakings in the EU, the figure assumed by the Commission appears underestimating. Even though the new requirements do not increase the number of reporting undertakings (significantly), they do have the effect of making the reports more comparable.

64 See the estimate by the Danish government on http://csrgov.dk/faq.

65 This is for instance clear from recital 14 of Directive 2014/95/EU, according to which other undertakings and groups may be required by the Member States to disclose information. In Denmark it has been proposed to implement the amending directive so as to require all 1,100 undertakings that report according to the current regime to report under the new EU regime, see Law L117 (Forslag til lov om ændring af årsregnskabsloven og forskellige andre love) proposed on 28.2. 2015. If this Danish gold plating 


\section{$I V$. What to disclose and how to do it}

\section{What should be disclosed?}

The phrasing of the amending directive is not entirely clear about which nonfinancial information should be disclosed by undertakings subject to the requirement. It mentions six CSR-related topics, which should be disclosed and five items in relation to which they should be disclosed. In addition, it provides for a standard, the 'necessary for an understanding' standard, to regulate the scope of the disclosure obligation and thereby avoid inadequate disclosure or information overload. Although they are discussed separately below in sections 4.1.1-4.1.3, the six topics, the five items and the 'necessary for an understanding' standard are very much connected and only reading them concurrently clarifies which information has to be disclosed according to the directive in the non-financial report.

\section{a. Six CSR-related topics expressly mentioned}

According to the new Article 19a and Article 29a of the Accounting Directive the undertakings should report on their activities relating to environmental, social and employee matters, respect for human rights, anti-corruption and bribery matters. It is clearly stated that reporting on these matters is the minimum. Therefore the undertaking can report on other matters if they so desire, but they need to report on these matters.

The amending directive has tried to balance different concerns. On the one hand, the directive needed to introduce a minimum requirement as otherwise it would not have been possible to secure an enhanced consistency and comparability of non-financial information. ${ }^{66}$ On the other hand, the regime still had to have sufficient flexibility to allow the reporting undertakings to report on the issues most relevant to them. ${ }^{67}$ The intention of the EU legislator was not to dictate how business activities are best made sustainable, but to leave it to the undertakings to find the best solution.

It is open for debate whether the solution chosen finds the right balance between the aforementioned concerns. By listing six specific CSR-related topics these will be given a special status. Undertakings that do not have any policies on these topics will have to explain why that is the case. This may be awkward

is passed into law, it will ensure that more than the expected 6,000 undertakings apply the new disclosure rules.

66 See recitals 5 and 6 of Directive 2014/95/EU.

67 Commission Staff Working Document, Impact Assessment, 16. 4.2013, p. 29. 
for an undertaking to explain and therefore there is an incentive to concentrate the undertaking's CSR activities on these six topics. This could have a negative impact if an undertaking chooses to direct its CSR activities on the six topics even though it would have made its activities more sustainable had the undertaking focused on a few of these and/or focussed on some other issues.

In comparison, the Danish regime originally only included a very broad definition of what constituted CSR and left it to the undertakings to decide which topics to report on. On the one hand, this solution had the benefit of allowing the undertakings to choose freely which activities to cultivate and report on. On the other hand, the reports became very diverse, hence comparability and consistency was clearly not achieved. In a revision of the rules in 2012 a duty was introduced to report specifically on two topics: human rights and climate mitigation. ${ }^{68}$ The intention with these rules was not to enhance comparability and consistency but to push an agenda according to which Danish undertakings were to focus more on making advances in respect of these two topics. ${ }^{69}$ When the legislation was passed, it was criticized by some organisations as it made these two topics more prominent than other CSR topics, which in many ways could have had the effect of too much effort being used to promote these topics even though many undertakings could have achieved a more significant impact had they focussed elsewhere. ${ }^{70}$

However, the critique of the Danish solution cannot be directed against the solution found in the amending directive. Since the directive focuses on six topics - and at that the six most common CSR issues undertakings report $\mathrm{on}^{71}$ - there is less risk that specifying these six topics will have an inappropriate effect on the focus of undertakings. Therefore the directive appears to

68 See law no. 546 dated 18.6.2012 (Lov om maglings- og klageinstitutionen for ansvarlig virksombedsadferd).

69 It appears that this strategy has succeeded. In 2011 only $18 \%$ of the undertakings reported on human rights, whereas no less than $42 \%$ of the undertakings reported on a human rights policy in the 2013 accounting year, see the report prepared by Cowi entitled 'Kortlegning af danske virksombeders redegørelse for samfundsansvar', available at http://samfundsansvar.dk/file/355819/samfundsansvar_rapportering_danmark. pdf, 2014.

70 This was pointed out by the Confederation of Danish Industry (DI) as well as the Danish Agriculture \& Food Council, an organisation that represents the farming and food industry of Denmark (Landbrug og Fødevarer), in their responses to the public hearing dated 23 January 2012 and 20 January 2012 respectively. See also the discussion in Birgitte Egelund Olsen \& Karsten Engsig Sørensen, Nye krav til virksombeders redegørelse for samfundsansvar, in: Mette Neville \& Engsig Sørensen (eds): Selskaberaktuelle emner, Jurist- og Økonomforbundet, 2013, p. 265.

71 The amending directive does not mention climate, but it appears that climate issues are covered by the term 'environmental', see below. 
have achieved a fair balance between the need to ensure flexibility and comparability.

The six topics are not defined in the text of the amending directive. However, on three points the preamble gives some additional hint as to the scope of some of them.

First, according to the preamble reporting on environmental matters should include details on the current and foreseeable impact of the undertakings operations on the environment and, as appropriate, on health and safety, the use of renewable and/or non-renewable energy, greenhouse gas emission, water use and air pollution. ${ }^{72}$ Thus it is clear that the term is very broad and also covers climate-related issues.

Second, the term 'social and employee matters' covers actions taken to ensure gender equality, implementation of fundamental convention of the International Labour Organisation, working conditions, social dialogue, respect for the right of workers to be informed and consulted, respect for trade union rights, health and safety at work and the dialogue with local communities. ${ }^{73}$ This is again a very broad concept that allows for the disclosure of different activities and policies. It is intriguing that gender equality is mentioned even though this issue is clearly also central for the special duty to report on diversity policy, which is also introduced with the amending directive. As a consequence, undertakings appear to be obliged to report on diversity both in their corporate governance statement and in the non-financial statement. However, since the issues that are reported in the two statements are not exactly the same, this dual reporting requirement appears justified. The diversity report in the corporate governance statement is only covering the top level of the undertaking. Equality policies that should be reported in the non-financial statement should cover activities directed to all levels of employees in the undertaking. Furthermore, such policies may also be pursued outside the undertaking.

Third, with regard to human rights, anti-corruption and bribery the preamble points out that the statement could include information on the prevention of human rights abuses and/or on instruments in place to fight corruption and bribery. ${ }^{74}$

72 See recital 7 of Directive 2014/95/EU.

73 Ibid.

74 Ibid. 


\section{b. The five items in relation to which the CSR-related topics should be reported on}

According to Article $19 \mathrm{a}$ and Article $29 \mathrm{a}$ of the amended Accounting Directive undertakings should report on their business model in relation to the above-discussed six CSR-related topics, the policies they adopted in relation to them, the outcome of these policies, the principal risks in relation to them and the KPIs in relation to them. ${ }^{75}$ Therefore it is clear that the undertaking has to disclose the aforementioned six topics in connection with these five items. There is little evidence why the EU legislator chose to adopt the reporting requirement in this form, but it may give a better structure to the disclosure and make the non-financial disclosure more closely tied to the undertaking's business activities and thereby even more relevant to the undertaking and to its investors and other stakeholders.

Based on the text of the amending directive it is possible to elaborate a little on each of the five items.

First, it is a condition that the topics mentioned in section 4.1.1 have to be reported on in connection with the undertaking's business model. For this reason there should be a brief description of the undertaking's business model. ${ }^{76}$ This stresses that the topics should only be reported on if and only to the extent they are relevant for the undertaking's business, see also section 4.1.3 below. If an activity has no relation to the business of the undertaking, but is for instance philanthropy, it should not be mentioned. This suggests a narrow interpretation of non-financial information. This is underpinned by the fact that the EU legislator sees the new requirements as a step towards a more resource-efficient Europe. ${ }^{77}$ No doubt, this requirement has been adopted in order to forge a closer link between the business model and the environment in which the undertaking operates and thereby to give birth to new innovative business models in the long term. ${ }^{78}$

Second, the statement should address whether the undertaking has a policy about at least the six topics listed in section 4.1.1, including the implemented due diligence procedures. This requirement does not prevent the policy to address other issues given that these six topics are the bare minimum. Apart from the pointers given above in section 4.1.1 the undertakings enjoy freedom in deciding which aspects should be addressed under each issue. The due

75 Article 19a(1)(a)-(e) and Article 29a(1)(a)-(e) of Directive 2013/34/EU.

76 See Article 19a(1)(a) of Directive 2013/34/EU.

77 See Recital 12 of Directive 2014/95/EU.

78 See EU Parliament, Committee of Legal Affairs, Report on corporate social responsibility: accountable, transparent and responsible business behaviour and sustainable growth, 2012/2098(INI), A7-0017/2013, 28.1.2013, p. 5. 
diligence procedures presumably refer to procedures through which the management checks the implementation of the policies throughout the undertaking; however, the amending directive does not clarify further what is meant by due diligence exactly relating to the policies.

Third, after accounting for the policies pursued the outcome of these policies should be described. ${ }^{79}$ There is a close link between these two reporting requirements and the Danish experiences show that not all reporting undertakings make this link. According to the Danish rules, undertakings should report on their policies on CSR first, then on how they intend to implement these policies and finally the outcome of these policies. Empirical research shows that not all Danish undertakings report on all three aspects and even if they do, there is a lack of consistency as they do not address the same policies under all three reporting items. ${ }^{80}$

Fourth, the non-financial statement should address the principal risks related to the six topics discussed in section 4.1.1. These risks should be described in relation to the undertaking's operation, including its business relationships, products or services that are likely to cause adverse impact. ${ }^{81}$ However, the disclosure should only include the risks that have already materialised and those risks that are most likely to have severe impact if they materialise. ${ }^{82}$ However, neither is it further explained how likely the materialisation of the risk should be, nor is it explained in more detail how severe the 'severe impact' should be to merit disclosure. In addition to this, the undertakings should report on how they manage those risks. According to recital 6 of the preamble, the matter should include '... information on the due diligence processes implemented by the undertaking, also regarding, where relevant and proportionate, its supply and subcontracting chains, in order to identify, prevent and mitigate existing and potential adverse impact'. Taken together there appears to be a requirement that both the nature of the risks involved and how these are managed are reported on, but it is foreseeable that a consistent reporting on these two aspects may not always be expected.

79 See Article 19a(1)(b)-(c) of Directive 2013/34/EU.

80 In the 2011 reporting year, thus several years after the Danish disclosure requirement had been enacted, only $44 \%$ of the examined reports was fully consistent, see the report Samfundsansvar og Rapportering i Danmark: Effekten af 3. ar med rapporteringskrav $i$ årsregnskabsloven, available at http://samfundsansvar.dk/file/355819/samfundsans var_rapportering_danmark.pdf, 2012, p. 17.

81 The terms 'business relationships' and 'adverse impact' are not defined in the directive, but similar terms are used in the OECD Guidelines for Multinational Enterprises. Since according to recital 9, undertakings may rely on international frameworks, including the OECD Guidelines for Multinational Enterprising, when reporting, it would make sense to use the definitions found in the Guidelines.

82 See recital 8 of Directive 2014/95/EU. 
Fifth, the statement should indicate the KPIs relevant to the particular business. ${ }^{83}$ However, neither the amended Accounting Directive, nor the preamble of the amending directive specify further which indicators or types of indicators should the undertaking use. That the preamble of the amending directive lists international and EU frameworks may give a hint of which indicators or which types of indicators the EU legislator was considering. In addition, the forthcoming Commission guidelines should also specifically include general and sectoral indicators, ${ }^{84}$ see in more detail in section 4.2. Further, since during the preparation of the guidelines the Commission should take into account current best practices and international developments, ${ }^{85}$ the EU legislator's intention of promoting the undertakings' reliance on already existing frameworks appears clear. At the same time, the undertakings still appear to have a free hand as to which indicators they choose to use in their disclosures.

\section{c. The 'necessary for an understanding' standard}

As a minimum, the undertakings should report on the six topics mentioned in relation to the five items, however, only 'to the extent necessary for an understanding of the undertaking's development, performance, position and impact of its activities' ${ }^{86}$ This standard, on the one hand, makes sure that only information that is important for the undertaking is included. Given that the non-financial statement is part of the management report and thus part of the annual report of the undertaking together with the annual financial statement, this qualification appears reasonable. Investors and other stakeholders are likely to be primarily interested in those activities which are important to understand how the undertaking is performing and developing. ${ }^{87}$ However, the inclusion of this standard may be used by the firm to neglect reporting on CSR activities because it does not directly affect the results of the undertaking.

A very similar standard exists in Article 19(1) third paragraph of the Accounting Directive according to which: 'To the extent necessary for an understanding of the undertaking's development, performance or position, the analysis shall include both financial and, where appropriate, on financial key performance indicators relevant to the particular business, including information relating to environmental and employee matters.' The latter provision has been

83 See Article 19a(1)(e) of Directive 2013/34/EU.

84 See para. 1 of Article 2 of Directive 2014/95/EU.

85 See recital 17 of Directive 2014/95/EU.

86 See Article 19a(1) of Directive 2013/34/EU.

87 CSR reports are often filled with information that have little or only marginal connection to the business. The undertaking can still make such a broad CSR report as a supplement to the non-financial statement. 
in place for years and has not resulted in any substantial reporting of environmental and employee matters. ${ }^{88}$ One of the reasons for this could be that the condition that the information should be necessary for the understanding of the undertakings' development etc. makes it easy for the undertakings to conclude that such a link is not established and thus the information can be omitted. It is worth contemplating whether there is a risk that some undertakings will use the very similar wording in the new reporting requirement to avoid reporting. In our opinion this is not likely to happen. Given that the new reporting requirement is much more detailed and elaborate, the pressure on the undertakings to report on the CSR-related topics is much stronger. Additionally, the duty to explain if no activities are reported is also making the undertakings less likely to avoid reporting altogether. ${ }^{89}$

In addition, the new requirement added 'impact of its activities' to the wording of Article 19(1) third paragraph. This phrase indicates more clearly that the reporting should be done to the extent it has bearing on how the activities of the undertaking impact the society at large. This is probably easier for managers and accountants to understand in actual situations than to understand when CSR activities have importance for understanding the development, performance and position of the undertaking in general. However, even though the standard is unlikely to cause significantly reduced reporting the standard may possibly be used to omit some information.

\section{The format of reporting}

In respect of the format, the new rules do not include strict requirements. There is, however, an indication of where the information should be disclosed and some indication of how it should be disclosed.

88 See Commission Staff Working Document, Impact Assessment, 16. 4. 2013, pp. 10-12.

89 Another risk worth contemplating is the risk that the requirements may give the undertakings an incentive not to perform CSR-related activities that fall outside the scope of the business activities, since other activities - no matter how beneficial they may be should not be included in the statement. However, since the amending directive only outlines the minimum requirements, there would not be anything preventing the undertaking from including the information in the statement, and therefore this risk seems even less likely to materialise. However, when implementing, the Member States may restrict the extent to which undertakings can insert additional information in the statement. This is for instance the case in Denmark where both the existing rules and the proposed rules implementing the amending directive suggest that undertakings may not insert additional information in the non-financial statement, but may only publish this elsewhere, for instance on the undertakings' webpage. 
As for where the information should be disclosed, it is required that the undertakings either include their non-financial statement in their management report or issue a separate report based on national, EU or international framework..$^{90}$ While reporting in the management report always fulfils the requirements of the amending directive, reporting using another framework is only in compliance with the directive if the competent Member State so decides, see further discussion in section 5.1. Further limitation in the latter case is that the separate report still has to be published together with the management statement or, within a reasonable time, on the undertaking's website. This approach is completely in line with the EU legislator's intention of providing a flexible non-financial reporting system in which different ways of complying with the requirement are equally accepted based on the different circumstances of individual undertakings and without creating unnecessary administrative burdens.

The Danish legislator also shares the opinion that the best place to disclose CSR information is in the management report. ${ }^{91}$ Additionally, the Danish legislation also provides for flexibility in the reporting requirement, similar to that in the EU corporate governance reporting rules, ${ }^{92}$ by permitting the disclosure of the CSR report as a separate document disclosed together with the management report, or as a completely separate document. ${ }^{93}$ However, the only condition that the undertaking has to meet in respect of the latter method of disclosure is that the place of disclosure of the CSR report has to be referred to in the management report. ${ }^{94}$ The Danish rules also allow for reporting under the reporting system of the UN Global Compact (UNGC), the Global Reporting Initiative (GRI) and the UN Principles for Responsible Investment (PRI). If a Danish undertaking makes a report under one of these three reporting schemes, they only have to make a reference to this fact in their manage-

90 See Article 19a(1) and (4) of Directive 2013/34/EU.

91 See Section 99a(4) of the Danish Financial Statements Act (Act no. 448 of 7 June 2001 with later updates).

92 See Article 1(7) of Directive 2006/46/EC of the European Parliament and of the Council of 14 June 2006 amending Council Directives 78/660/EEC on the annual accounts of certain types of companies, 83/349/EEC on consolidated accounts, 86/635/EEC on the annual accounts and consolidated accounts of banks and other financial institutions and 91/674/EEC on the annual accounts and consolidated accounts of insurance undertakings, OJ L 224, 16. 8. 2006.

93 See Section 99a(4) of the Danish Financial Statements Act.

94 See Section 99a(4) of the Danish Financial Statements Act. According to the report Kortlegning af danske virksombeders redegørelse for samfundsansvar, available at http://samfundsansvar.dk/file/355819/samfundsansvar_rapportering_danmark.pdf, 2014 , p. 16, as many as $50 \%$ of Danish undertakings referred in their management report to a report on the web which was either supplementing the information on CSR given in the management report (40\%) or making it up the CSR report (10\%). 
ment report. ${ }^{95}$ Although, the new EU rule does not provide for all these possibilities, the structure introduced by the amending directive does make it easier to find the reports and the information, as they will always be in or attached to the management report or will be on the undertaking's website. This should make comparisons easier if the same format is imposed (see discussion below). On the other hand, it makes the use of the internationally recognised reporting schemes less attractive, since reporting according to these will have to be done as a supplement to reporting under the general rules of the Accounting Directive. However, the Directive may allow the Member State to implement solutions that allow for alternative reporting, see section 5.1 below.

As for how the information should be disclosed there are only slight indications. First of all, the topics that should as a minimum be reported on are listed, see section 4.1.1. However, the amending directive does not indicate what should be covered under each topic. The five items discussed in section 4.1.2 give some more insight into how the six topics should be presented. These five items not only give some rudimentary structure to the disclosure, but also imply what type of information the EU legislator is anticipating in the disclosures. The requirement appears to be moving from items more likely requiring qualitative information disclosure to ones more likely requiring quantitative information disclosure. For instance, while the business model is likely described by qualitative information, the disclosures relating to KPIs should include significantly more, even if not only, quantitative data. At the same time, the amending directive does not elaborate further on this issue; thus it is up to the preference of the individual undertaking to decide in what form to report on the six topics and five items and whether to disclose more qualitative or quantitative information.

The amending directive does not provide much insight into the order in which the topics and items should be presented either. Even though it would be logical to address the six topics in the order listed in the directive there is no obligation to do so. This statement similarly applies to the five items. For instance, as discussed above in section 4.1.2, undertakings should disclose their policies about the six topics and then the results of these policies. However, in theory they are not even obliged to make the disclosure in this order, although this would certainly be more logical.

Therefore, even with the indications discussed above as to the format it appears that the undertakings have a pretty free hand in deciding how to draw up

95 See Order No. 1543 of 16 December 2013, $\$ \$$ 2-3, implementing the Danish Financial Statements Act $₫ 99 \mathrm{a}(9)$. According to the report Kortlegning af danske virksombeders redegørelse for samfundsansvar, available at http://samfundsansvar.dk/file/355819/sam fundsansvar_rapportering_danmark.pdf, 2014, p. 16, 31\% of the Danish undertakings referred to a report under one of the three reporting schemes. 
the report and how to present the required information. Thus it can be foreseen that the undertakings will use very different formats in their reporting and it will be difficult for the users of these reports to make comparisons.

To overcome this problem the amending directive requires the Commission to adopt non-binding guidelines on the methodology for reporting by December 2016. ${ }^{96}$ Although, in theory such guidelines could improve the quantity, consistency and comparability of the disclosed non-financial information, this effect is not guaranteed. According to Danish experience, while the Danish reporting guideline expressly refers to the desirability of reporting on CSR indicators, ${ }^{97}$ for example in accordance with the GRI guidelines, less than $40 \%$ of the undertakings used any CSR indicators, ${ }^{98}$ but rather reported on their CSR using qualitative descriptions. ${ }^{99}$ At the same time also less than one-third of the undertakings reported on negative events in respect of their CSR and on more complex CSR dilemmas. ${ }^{100}$ This means that while such a flexible setup, together with non-binding guidelines, may increase the quantity of information disclosed, but this increase is not necessarily paralleled by an increase in the consistency and comparability of the information disclosed. ${ }^{101}$ Although, it has to be acknowledged that this effect is greatly dependent on the formulation and level of detail of the particular guidelines, as well as the extent to which they are accepted by the undertakings as best practice.

As the amending directive follows a minimum harmonisation approach, the Member States may also choose to adopt stricter policies on the format of the

96 See Article 2 of Directive 2014/95/EU, where it is specified that the guidelines should cover the methodology for reporting, including general and sectoral KPIs. Recital 17 of the amending directive also indicates that in respect of the environmental aspects the guidelines should at least cover land use, greenhouse gas emissions and the use of materials.

97 Proposal for an Act amending the Danish Financial Statements Act (2008), p. 8.

98 Corporate Social Responsibility and Reporting in Denmark: Impact of the legal requirement for reporting on CSR in the Danish Financial Statements Act (available at http://www.dcca.dk/graphics/publikationer/CSR/CSR_and_Reporting_in_Den mark.pdf, 2010), p. 12.

99 Corporate Social Responsibility and Reporting in Denmark: Impact of the third year subject to the legal requirements for reporting on CSR in the Danish Financial Statements Act, available at http://samfundsansvar.dk/file/358879/csr_rapport_2013_eng. pdf, 2012, p. 23.

100 Ibid., p. 21.

101 Thus interestingly a survey undertaken by KPMG from 2011 indicated that even though the number of undertakings reporting on CSR was very high in Denmark, Denmark did not do well on the parameter 'Quality of communication' as Denmark was the last one out of the 34 countries examined. See KPMG, International Survey of Corporate Responsibility Reporting 2011, available at http://www.kpmg.com/Global/ en/IssuesAndInsights/ArticlesPublications/corporate-responsibility/Documents/ 2011-survey.pdf, 2011. 
reports. Although this may improve the quantity of information and the consistency of the reports in some Member States, it is clear that few, if any, Member States would adopt stricter additional mandatory requirements, considering the projected costs of such an approach. ${ }^{102}$ The diverging rules in different Member States would surely not serve the goal of establishing a level playing field in the area and of increasing the comparability of the reports on the EU level. At the same time, it will be interesting to see the Member States' reactions to the forthcoming Commission guidelines, since depending on the quality and level of detail of the guidelines, some Member States may choose to adopt those as binding in their jurisdiction.

Finally, it is worth mentioning that the EU legislator has chosen not to adopt the format of integrated reporting. Given that much effort has been used in recent years to develop such a form of reporting, it is likely that this will be seen by many as a missed opportunity. ${ }^{103}$ This is certainly true of the European Parliament that would have supported a more ambitious amendment of the Accounting Directive prescribing the adoption of integrated reporting as being developed by the International Integrated Reporting Council. ${ }^{104} \mathrm{How}-$ ever, the approach taken by the amending directive may reflect the fact that even though integrated reporting sounds promising, it is still far from being developed into a feasible solution. The impact assessment of the Commission points out that since the initiative of the Integrated Reporting Council is in its infancy, significant results can only be expected in the medium/long term. ${ }^{105}$ This provides compelling evidence that the adoption of a reporting regime relying entirely on this new and fundamentally different reporting standard would have been premature at this stage of its development.

\section{Duty to explain if no policies are pursued}

According to the second paragraph of Article 19a(1) an undertaking that does not pursue policies in relation to one or more of the six topics discussed in section 4.1.1 should explain why this is the case. The explanation should be 'clear and reasoned'. 106

102 See Commission Staff Working Document, Impact Assessment, 16. 4. 2013, pp. 24-31.

103 So David Monciardini, Regulating Accounting for Sustainable Companies: Some Considerations for the Forthcoming EU Directive, European Company Law, vol. 11, issue 2, 2014, pp. 121-124.

104 EU Parliament, Committee of Legal Affairs, Report on corporate social responsibility, 28.1.2013, p. 18.

105 Commission Staff Working Document, Impact Assessment, 16. 4. 2013, p. 21.

106 The duty to explain is formulated in exactly the same terms for consolidated statements, see para. 2 of Article 29a(1) of Directive 2013/34/EU. 
With this the amending directive introduces a duty to explain, which is not unlike the comply-or-explain principle that has been applied in the area of EU corporate governance since Directive 2006/46/EC came into force. If an undertaking is not complying with the relevant recommendation of the applicable corporate governance code, it should explain why this is the case. Similarly there is an underlying recommendation in this case that undertakings should have policies on all six CSR topics as they will otherwise have to explain why that is not the case. The probable effect of this duty is that undertakings will at least consider having policies on all six topics. However, despite of the possible beneficial effect of the undertakings adopting such policies in general, some undertakings may adopt hollow policies, lacking real substance, just to be in compliance with the recommendation. This 'box-ticking' approach has often been seen as one of the disadvantages of the 'comply-orexplain' principle and similar-style narrative reporting in general. ${ }^{107}$

Another weak point of the duty to explain is that in all likelihood not all undertakings will give informative explanations. There is a lot of evidence that the comply-or-explain principle vis-à-vis the corporate governance statement does not always work as intended. An examination of corporate governance disclosures in 2009 showed that only $39 \%$ of the explanations given were informative, and the rest were categorised as invalid, general or limited. ${ }^{108}$ Part of the reason for this is that the comply-or-explain rule itself does not prescribe a uniform reporting format. Although Directive 2006/46/EC introduces a comply-or-explain obligation, it does not elaborate on how and according to which criteria, the explanations should be given, which obviously leaves wide discretion to undertakings on how to formulate the explanation.

The Danish experiences also indicate that there is a danger that the explanation for not having a CSR policy will not always be informative. The Danish CSR

107 Charlotte Villiers and Barry Rider, Corporate reporting and company law (Cambridge University Press, 2006), p. 214; Karsten Engsig Sørensen, Disclosure in EU Corporate Governance - A Remedy in Need of Adjustment? (European Business Organization Law Review (EBOR), Vol. 10, Issue 2, 2009), p. 269.

108 See the RiskMetrics Group, Study on Monitoring and Enforcement Practices in Corporate Governance in the Member States, available at http://ec.europa.eu/internal_ market/company/docs/ecgforum/studies/comply-or-explain-090923_en.pdf, 2009, p. 84. Other studies confirm that explanations are often not very informative, see Iain MacNeil \& Xiao Li, 'Comply or Explain': Market Discipline and Non-compliance With the Combined Code, Corporate Governance: An International Review, vol. 14, 2006, examining companies which comply or explain under the UK Combined Code; Maja Kragh-Schwarz, Comply or Explain, virker det?, Nordisk Tidsskrift for Selskabsret, no. 4, 2007; and Eva Parum, Does Disclosure on Corporate Governance Lead to Openness and Transparency in How Companies are Managed?, Corporate Governance: An International Review, vol. 13, issue 5, 2005, examining disclosure by companies listed on the OMX stock exchange in Copenhagen. 
disclosure regime does not require explanation, but the Danish corporate governance code recommends for the central governing body of the undertakings to adopt a policy on CSR. ${ }^{109}$ A survey made by the authors of how Danish undertakings responded to that recommendation showed that out of 186 listed companies 55 did not comply with the recommendation. ${ }^{110}$ Some of the explanations given by the 55 companies were informative, but many were more or less unclear, and in six cases there was no attempt at all to explain why they did not comply. Overall, the Danish experience shows that the explanations tend to be very short and not too informative, which is a risk in the case of the non-financial statement as well.

Therefore, foreseeably there will be a need for more specific guidelines on what constitutes 'clear and reasoned' explanations. In 2014, the Commission published some guidelines for explanations on corporate governance issues. ${ }^{111}$ These are not applicable to the explanations required under the amending directive, but they could be an inspiration for future guidelines. Article 2 of the directive empowering the Commission to issue guidelines does not specifically refer to guidelines on how to make explanations, and it is not one of the issues that are suggested in recital 17 of the preamble. Nevertheless, it appears advisable to make such recommendation if the duty to explain is going to have the desired informative effect.

\section{Exceptions to the duty to disclose a non-financial statement}

The amending directive allows for exceptions from the duty to report in two situations. Firstly, publishing a non-financial statement may be avoided where disclosure is made in a report that follows an alternative framework. Additionally, certain information may be omitted from the statement in exceptional cases.

109 See the Recommendations on Corporate Governance, prepared by the Committee on Corporate Governance, latest updated version from November 2014, recommendation 2.2.1 (available at http://corporategovernance.dk/recommendations).

110 See Dániel Gergely Szabó \& Karsten Engsig Sørensen, Integrating Corporate Social Responsibility in Corporate Governance Codes in the EU, European Business Law Review, vol. 24, no. 6, 2013, pp. 781-828. The survey included all the latest annual reports published at the time of the examination in November 2011.

111 See Commission Recommendation 2014/208/EU of 9 April 2014 on the quality of corporate governance reporting ('comply-or-explain'), OJ L 109, 12.4. 2014. 


\section{Reporting under alternative frameworks}

Instead of making a non-financial statement undertakings may produce a separate report drawn up according to an alternative, national, union-based or international framework. ${ }^{112}$ The preamble mentions a couple of examples of such frameworks: Eco-Management and Audit Scheme (EMAS), UN Global Compact, OECD Guidelines for Multinational Enterprises, ISO 26000 and Global Reporting Initiative. ${ }^{113}$

If the undertaking chooses to make a separate report according to such an alternative framework, the Member State may exempt it from the obligation to make a non-financial statement, if a number of conditions are fulfilled. Firstly, the alternative report should cover the same financial year. Secondly, it should either be published together with the management report or on the website of the undertaking and with a reference to the website in the management report. ${ }^{114}$ Thirdly, the report should be '.. covering the information required for the non-financial statement'. It is not clear to what extent the alternative report should correspond to the requirements of Article 19a(1) or Article 29a(1) of the Accounting Directive. Would it be enough that the statement covers the six topics listed as a minimum? Or is it also required that the five items, see section 4.1.2, are also touched upon and that the format of reporting required by the new provosions of the Directive are followed? These are essential questions, since although most sustainability or CSR frameworks facilitate or require the disclosure of information on the undertaking's policies and KPIs related to the six topics, not all of them require disclosure about the undertaking's business model or its principal risks.

There is no clear indication of how the condition should be interpreted. According to para. 6 of the preamble of the amending directive, exemption should only be given if the alternative report is 'covering the same content'. This wording is not conclusive either, but most likely points towards that all information required in Article 19a(1) or Article 29a(1) should be provided in the alternative report. Given that the wording is not clear, a teleological interpretation is called for. On the one hand, the exemption aims at authorizing the use of alternatives, which indicates that some flexibility should be allowed when judging whether the same content is covered. On the other hand, the directive aims at enhancing consistency and comparability, and these aims are jeopardized the more the alternative reporting differs from the non-financial statement. However, on balance it appears that the very fact that an exception

112 See the Article 19a(4) and Article 29a(4) of Directive 2013/34/EU in regard to the consolidated statement.

113 See the list in full in recital 9 of Directive 2014/95/EU.

114 See Article 19a(4) of Directive 2013/34/EU. 
has been introduced for alternative frameworks, indicates that undertakings making use of alternative frameworks are given some flexibility in complying with the reporting requirements of the directive if the alternative frameworks so require. Since there are some international frameworks that are likely to be popular with undertakings in all Member States, there is probably a need to develop a common understanding how Member States should apply their discretion of exempting undertakings in relation to these frameworks.

Member States may also decide to uphold or introduce alternative national reporting standards. This is also allowed for in the exception, although alternative national frameworks seem likely to make comparisons between undertakings across Europe more difficult. Therefore the exception for these frameworks may have to be interpreted more rigidly, allowing for fewer possibilities of diverging from the requirements of the amending directive. For instance it appeared doubtful whether the Danish reporting rules could be upheld as an alternative framework, since on some points the reporting requirements deviated from those of the directive. However, this discussion appears to be closed even before it started, as in early 2015 the Danish government proposed a reform of the Danish rules requiring Danish undertakings to report according to the provisions of the directive. ${ }^{115}$ Thus the Danish government proposes giving up the reporting requirements Denmark had in place since 2009 and adopting the new EU reporting requirements instead.

\section{Commercial secrets}

Member States may also allow information relating to impending developments or matters in the course of negotiations to be omitted in exceptional cases where the disclosure of such information would be seriously prejudicial to the commercial position of the undertaking. ${ }^{116}$ There are a number of conditions attached to the application of this exception. Firstly, the management bodies of the undertaking should approve it. The amending directive does not say which bodies should be involved but refers to the fact that it should be a

115 See proposal L117 (Forslag til lov om xndring af årsregnskabsloven og forskellige andre love) proposed on 28.2.2015. The law is expected to be adopted before the summer of 2015.

116 See the fourth paragraph of both Article 19a(1) and 29a(1) of Directive 2013/34/EU. The reason for including this exemption appears to be that otherwise there would be a risk of the disclose duty jeopardizing fundamental rights. According to recital 22 of the preamble to the Directive 2014/95/EU, the directive respects the fundamental rights including the freedom to conduct business, respect for private life and the protection of personal data. It is clear that the exemption will have to be interpreted in a way that avoids conflict with the fundamental rights. 
body acting within the 'competences assigned to them by national law'. This must indicate that the body which is assigned the competence to make such a decision according to national law should take the decision. It is stressed that there is a collective responsibility for taking this decision. The final condition is that the omission may not prevent a fair and balanced understanding of the undertaking's development, performance, position and impact of its activity.

This exception should clearly be used with care. It appears most likely that it should only be used for information about developments that are just taking place or that will take place in the near future. Thus information about the past will not likely be covered. For instance it could be tempting for an undertaking to conclude that it would be prejudicial to disclose information about environmental damages caused by it since this could jeopardize ongoing negations or harm the undertaking's reputation and therefore future sales. But since this information mainly relates to matters that have already taken place, the exception is not likely to apply.

The amending directive does not dictate how the Member States should authorise the omission. They will most likely choose a solution where they leave it to the undertakings to exercise the exemption. However, this solution will obviously give the undertakings a wide discretion and may result in retroactive (judicial) reviews and a level of uncertainty until steady practice on the application of the new rules is established. Alternatively, Member States can require the undertakings to ask for permission in advance in each individual case if information is to be omitted. Such a solution would ensure that the exemption is only used when the special circumstances are present; however, this solution may be burdensome for the Member States to operate. Better results could be achieved if the Member States - or rather the Commission - made some guidelines as to when the exemption may be relied on.

\section{Enforcement}

\section{Auditors role}

The main enforcement mechanism related to the non-financial reporting requirements is a compulsory check by the auditor. However, the Member State should only ensure that the auditor checks the existence of the non-financial statement or, if so provided by the Member State law, the existence of the separate report prepared using national, EU or international frameworks. ${ }^{117}$ Checking the content of these reports in any way is not a mandatory requirement posed by the amended Accounting Directive. This is not only a signifi-

117 See Article 19a(5) of Directive 2013/34/EU. 
cant step back in comparison to the proposal for the amending directive, ${ }^{118}$ but also in comparison to the original non-financial reporting requirement adopted in $2003 .{ }^{119}$ Both of these required a consistency check of the nonfinancial information, which meant that the auditor had to cross-check the consistency of the representations in the management report with the data in the annual financial accounts. ${ }^{120}$ Although the consistency check is a weaker form of verification than the audit of the financial accounts, this is still a more substantive form of verification than the one adopted by the amending directive.

The EU Parliament's Report making this amendment to the original Proposal does not explain why the auditing requirement has been downgraded or how it should be complied with. ${ }^{121}$ Therefore, it is uncertain whether the audit complies with this requirement purely by expressing an opinion about the existence of a non-financial statement irrespective of the content thereof or whether the opinion should also include the verification of the existence of the mandatory elements listed in section 4 . Since the amending directive follows a strongly emphasized minimum harmonisation approach, it is more likely that only the formal existence of the report should be verified. This is underpinned by the fact that in respect of diversity information the individual elements that have to be reported on are required to be verified specifically. ${ }^{122}$ At the same time, Member States are free to adopt rules that oblige undertakings to get the content of their non-financial statements verified by independent assurance services providers. ${ }^{123}$ Although this would certainly increase the consistency of the information in the non-financial statements, it would not create a level playing field, since probably not all Member States would implement such a requirement.

If an undertaking is exempted either because it claims to be included in a consolidated non-financial statement, see section 3 above, or because it uses an alternative framework allowed by Member State law, see section 5.1 above, the auditor should also verify the existence of the consolidated statement or the alternative report. Again it should not be necessary to verify that the content complies with the directive. However, in some cases it may be difficult

118 See recital 14 of the Proposal for a Directive, $\operatorname{COM(2013)~} 207$ final, 16. 4.2013.

119 See Articles 1(17)-(18) and 2 (11) of Directive 2003/51/EC.

120 Ibid.

121 EU Parliament, Committee of Legal Affairs, Report on the proposal for a directive of the European Parliament and of the Council amending Council Directives 78/660/EEC and $83 / 349 / E E C$ as regards disclosure of non-financial and diversity information by certain large companies and groups, COM(2013)0207 - C7-0103/2013 - 2013/0110(COD), 10.01.2014.

122 See Article 20(3) of Directive 2013/34/EU.

123 See Article 19a(6) of Directive 2013/34/EU. 
to decide how far the auditors should go in their verification procedure. If, for instance, an undertaking is allowed to report under the UNGC as an alternative framework, the auditor would at least have to examine whether the undertaking has joined the Global Compact. But should he or she also examine whether it has a progress report covering the most recent financial year, or is it enough if he or she checks whether the undertaking's status is active or non-communicating? The answer to this would probably have to be specified by the Member State that allows for the use of the alternative reporting framework. ${ }^{124}$

Despite of its deficiencies at first sight, such a setup of verification by the auditor instead of a consistency check is not completely unfounded. It is not clear whether a consistency check would improve the quality of the statement substantially. It can be rather difficult to assess whether the content of the non-financial report is consistent with the financial data in the annual accounts, since such primarily narrative information is difficult to quantify, and auditors may also lack the expertise to assess the accuracy of non-financial information. ${ }^{125}$ The Danish experience with mandatory CSR disclosure also shows that despite of the more stringent requirement of consistency check, in the first three years of the application of the requirement the auditors often failed to even comment in cases where no CSR report was published by an undertaking. ${ }^{126}$ In light of this a more rigorously enforced formal verification requirement may be more prudent at this stage of the development of the nonfinancial reporting area.

\section{Additional enforcement mechanisms}

Given that the involvement of auditors may not necessarily ensure full compliance with the new provisions of the Accounting Directive, additional enforcement mechanisms may be needed. According to Article 33(1) of the Directive the members of the administrative, management, and supervisory bodies have collective responsibility for the management report. This provision is amended to ensure that if the non-financial statement is given in a separate statement according to Article 19a(4) or Article 29a(4), the aforementioned bodies' responsibility extends to this separate report. Thus it is ensured that these bodies cannot escape responsibility by using an alternative reporting

124 In Denmark the auditor would have to verify that there is a recent progress report, see Birgitte Egelund Olsen \& Karsten Engsig Sørensen, Virksombeders redegørelse for samfundsansvar, Juristen, 2009, pp. 177-188 (at p. 183).

125 Villiers and Rider, Corporate reporting and company law (2006), p. 222.

126 Corporate Social Responsibility and Reporting in Denmark: Impact of the third year (2012), pp. 25-26. 
framework. Additionally, the collective responsibility for exercising the right to omit information where it would be seriously prejudicial to the undertaking is emphasised by the Directive. ${ }^{127}$

Furthermore, the amending directive indicates that the Member States should implement additional enforcement mechanisms. According to recital 10 of the preamble of the directive Member States should ensure that adequate and effective means exist to guarantee disclosure in compliance with the directive. To that end, the Member State should ensure that effective national procedures are in place to enforce compliance and that those procedures are available to all persons and legal entities having a legitimate interest in ensuring that the provisions of the amending directive are respected. Apart from this paragraph of the preamble, however, there is nothing to support that such procedures should be introduced or how this additional enforcement mechanism should be construed. All-in-all, the directive is open for different interpretations on this point, especially since the requirement of additional enforcement mechanisms has not found its way into the directive itself, but only to the preamble. ${ }^{128}$ However, it does not seem likely that access to the national courts would be sufficient to implement the directive on this point, so the Member States should open up for some alternative complaint mechanisms. Most likely it should at least be possible to complain if there is no non-financial statement (or no alternative report), or complain if not all the information stipulated in Article $19 \mathrm{a}(1)$ is included in the statement. It is less clear whether stakeholders should also be able to complain if the information disclosed in the statement (or separate report) is wrong or misleading.

\section{Conclusion}

The disclosure regime adopted in the amending directive is quite comprehensive and appears to be in line with the current best practices of regulating nonfinancial, CSR or sustainability reporting. Therefore it is definitely a step forward on the EU level. But that is not to say that it is likely that the directive will be implemented and its provisions will work without posing any problems for the Member States and undertakings.

127 See para. 4 of both Article 19a(1) and Arcticle 29a(1) of Directive 2013/34/EU.

128 Normally, remarks in the preamble which are not in any way reflected in the main text of the Directive should not impose additional duties, see para. 54 of C-162/97, Gunnar Nilsson. But the situation is different in this case since there is a general duty to ensure effective sanctions of EU law, see for instance Case 14/83, von Colson, and the preamble may be seen as a reflection as to how this duty should be interpreted in relation to this specific directive. Therefore the Member States can hardly ignore the call for additional enforcement mechanisms. 
The new requirements do provide a more elaborate structure and more specific requirements than the previous rules on the EU level. Although this ensures that the new directive will have effect on the quantity of information disclosed and may increase the consistency and comparability of the reports, the latter effects only manifest if further measures are taken to ensure the reporting quality. Otherwise, the increase in quantity may not be paralleled by increased consistency and comparability of the reports, as was identified in the Danish experience.

Regrettably, the latter scenario seems likely to occur, as the Commission estimates the costs of the reporting at a very low figure. It appears obvious that such a low-cost approach based on minimum harmonisation, not supported by detailed rules and standards on the collection and processing of the information, is not likely to have a significant effect. After all, there is no such thing as a free lunch. Thus there is a significant danger that the EU legislator will get exactly what it was willing to pay for. 